\title{
Malnutrition during lactation as a metabolic imprinting factor inducing the feeding pattern of offspring rats when adults. The role of insulin and leptin
}

\section{A.S. Moura', \\ C.C.N. Franco de Sá ${ }^{1}$, \\ H.G. Cruz ${ }^{1}$ and \\ C.L. Costa ${ }^{2}$}

\author{
'Laboratório de Fisiologia da Nutrição e do D esenvolvimento, \\ Departamento de Ciências Fisiológicas, \\ Instituto de Biologia Roberto Alcântara Gomes, and \\ Instituto de Nutrição, Departamento de Nutrição Aplicada, \\ Universidade do Estado do Rio de Janeiro, Rio de Janeiro, RJ, Brasil
}

\section{Abstract}

\section{Correspondence}

A.S. Moura

Laboratório de Fisiologia da Nutrição e do Desenvolvimento Departamento de Ciências Fisiológicas

Instituto de Biologia Roberto Alcântara Gomes, UERJ Av. 28 de Setembro, 87 fundos 20550-030 Rio de Janeiro, RJ

\section{Brasil}

Fax: + 55-21-2587-6129

E-mail: asmoura@uerj.br

Research supported by CNPq (No. 520106/96) and FAPERJ (No. E-26/1711300/95).

Received September 13, 2001 Accepted March 8, 2002
The aim of the present study was to determine the impact of malnutrition during early postnatal life and the feeding pattern of rat offspring when adults ( 2 months and 1 year old). In comparison with rats normally fed during lactation, we observed that adult offspring displayed a faster process of feeding reduction when a protein-free diet was offered. In addition, we studied the concentration of insulin and leptin in the lactating pups (10 days) and when these offspring became adult after the onset of a new feeding pattern induced by the proteinfree diet. When the diet was changed at 60 days, the offspring malnourished during lactation displayed, after 3 days, a food intake reduction around $41.4 \mathrm{vs} 14.2 \%$ of the control group. At 10 days of life, plasma leptin and insulin were higher in the malnourished pups when compared with normally fed rats (leptin: $4.6 \pm 0.8$ vs $2.25 \mathrm{ng} / \mathrm{ml}$; insulin: $0.73 \pm 0.12$ vs $0.22 \pm 0.03 \mathrm{ng} / \mathrm{ml}$ ) while at 60 days they showed reduction of both hormones when compared with the control group (leptin: $1.03 \pm 0.25$ vs $1.43 \pm 0.5 \mathrm{ng} / \mathrm{ml}$; insulin: $0.54 \pm 0.3$ vs $0.61 \pm$ $0.4 \mathrm{ng} / \mathrm{ml}$ ). Despite the different food intake reductions, the malnourished and control rats displayed a similar reduction of insulin and leptin after 3 days of protein-free diet (from 60 to 63 days). The data suggest that the high concentration of insulin and leptin found at 10 days in the malnourished pups may elicit a sustained long-term and unique feeding pattern.

\section{Introduction}

Although malnutrition during gestation has been considered to play a putative longterm role for the predisposition to obesity, vascular disease and diabetes mellitus type 2 (1-3), there are few reports on the effects of early postnatal malnutrition in chronic diseases. Therefore, little attention has been

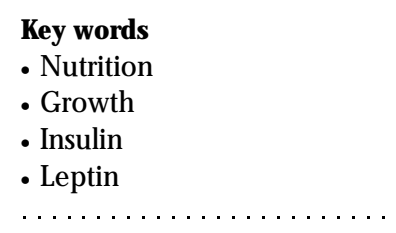

paid to the surprising observation that animals malnourished during lactation display a different weight gain and food intake development when compared with offspring from dams malnourished during gestation or normally fed (4).

Weight gain and feeding are mainly modulated by neural and hormonal inputs to the hypothalamus. Leptin, a hormone primarily 
secreted by adipose tissue $(5,6)$, and pancreatic insulin have recently elicited attention as important modulators of the hypothalamus in terms of feeding patterns and energy expenditure (7). In addition, it has been shown that the action of these hormones on the feeding regulatory mechanisms, mainly through the hunger modulator neuropeptide $\mathrm{Y}$, is fully present very early on in life and is sensitive to nutrient modulation (8). Nevertheless, it is still not known whether leptin and insulin participate in the characteristic feeding and growth pattern of animals malnourished during the early postnatal period (lactation).

Recent data have shown that the actions of leptin and insulin are mutually dependent on the modulation of intermediary metabolism (9). Insulin regulates the $o b$ gene in vivo or in vitro and leptin enhances the insulin action in different tissue (10). In previous studies with rats, we showed that malnutrition early in lactation induces long-term alterations in energy homeostasis when rats become adult. Basically, unlike the effect of malnutrition during gestation and/or lactation $(11,12)$, during the early lactation period (the first 10 days) a reduction of insulin secretion and an increase of insulin sensitivity were induced in the animals (13-15).

In the present investigation, we postulated that early malnutrition is associated with unique feeding patterns of the offspring when adults ( 2 months and 1 year old), and that early high insulin and leptin concentrations found in the lactating pups at 10 days of age are associated with the different feeding patterns found in the offspring when adults.

\section{Material and Methods}

Virgin rats (200-220 g) were mated and the pregnant dams were randomly housed in individual cages at $23 \pm 2^{\circ} \mathrm{C}$ on a 12-h light/ dark cycle (7:00-19:00 h). The dams were fed ad libitum a $22 \%$ protein diet during gestation. After delivery each lactating dam was kept with six pups (16) in two groups. In order to avoid data from pups delivered by the same dam, six females were malnourished during the first 10 days of lactation with a protein-free diet (PFD) and only one lactating pup from each dam was sacrificed at 10 days of age $(\mathrm{N}=6)(\mathrm{ML1}=$ malnourished diet during lactation, age $=10$ days); the control group was similar to the latter but the pups were from dams fed a normoprotein $\operatorname{diet}(\mathrm{N}=6)(\mathrm{NL} 10=$ normoprotein $\operatorname{diet}$ during lactation, age $=10$ days). After weaning, the study was divided into two stages.

During the first, we observed the effect of malnutrition during early lactation that induced differential weight gain and food intake in the animals when they were adults. In this part of the study 1-year- and 1 year and 3-month-old animals were used. Two groups were studied: a control group fed a normoprotein diet (22\% protein) (NLa) throughout the experiment and a second group which was undernourished during the first 10 days of lactation by feeding the dams a PFD (MLa). After one year of age, both groups were submitted to two periods of malnutrition with a PFD for 30 days. The periods were separated by a nutritional recovery period of 60 days (both groups were fed a $22 \%$ protein diet).

In the second part of the study, pups from both groups (NL and ML) were divided into two groups. To study the effect of changing the diet on body weight, food intake and insulin and leptin levels, after weaning (21 days), 36 pups from 36 dams malnourished or not during the first 10 days of lactation were housed in individual cages from weaning until 60 or 63 days of age, when they were studied. Basically, groups of six randomly selected offspring from the undernourished or normoprotein fed lactating dams were sacrificed at 60 and 63 days of age (submitted or not to a PFD during the last 3 days) (groups NL60 $=$ normoprotein diet during lactation, age $=60$ days; ML60 $=$ malnourished diet during lactation, age 60 
days; NL63 = normoprotein diet during lactation and studied at 63 days of age, with the diet changed at 60 days, and ML63 = malnourished diet during lactation and studied at 63 days, with the diet changed at 60 days) were malnourished during the first 10 days of lactation with a PFD (ML group), and the second group was made up of dams fed a normoprotein diet during lactation (21 days).

Weight gain and food intake were measured every 3 days. All experiments were done between 9:00 $\mathrm{h}$ and 11:00 $\mathrm{h}$. The animals were cared for in accordance with the principles set out in the Guide to the Care and Use of Experimental Animals (Committee on Care and Use of Laboratory Animals, National Research Council, USA, 1985).

Plasma insulin of the rats at 10,60 and 63 days of age was measured by radioimmunoassay. Monoiodinated insulin [ $\left.{ }^{125}\right]$ (Amersham Life Science Inc., Cleveland, OH, USA) was diluted in a solution of $10 \mathrm{mM}$ sodium phosphate, $5 \%$ bovine albumin, $\mathrm{pH} 7.4$, and guinea pig anti-insulin antibody diluted to 1:200,000 (kindly provided by Dr. William Mallaisse, Brussels, Belgium). For the standard curve, cold rat insulin was used (Crystal Chemical Inc., Chicago, IL, USA) $(17,18)$. Leptin was measured in the same plasma by ELISA (Leptin Elisa Kit DSL-10-241000, Active, Diagnostic Systems Laboratories Inc., Webster, TX, USA).

The diet used to induce malnutrition was isocaloric in relation to the control diet. The diet supplementation with vitamins and minerals was based on the recommendations of the American Institute of Rodent Nutrition Diets (19). The basic diet composition was cornstarch, soy oil and a mixture of vitamins and salts.

The results are reported as mean $\pm \mathrm{SEM}$. Data for the control and malnourished groups were compared by the Student $t$-test, with the level of significance set at $P<0.05$. When necessary, values were compared by analysis of variance (ANOVA) for repeated measurements.

\section{Results}

Figure 1 shows the body weight and food intake of the control adult animals (NLa) and adult (1 year old) undernourished animals during the first 10 days of lactation (MLa). After the control diet was replaced with the PFD, the weight of both groups decreased similarly. Food intake reduction (FIR) was different when the groups were compared. As shown in Figure 1, the FIR of the NLa was $49 \%$ during the first period of PFD (from $14.9 \pm 0.3$ to $7.6 \pm 0.15 \mathrm{~g} \mathrm{diet} /$ day) and $27.2 \%$ during the second period of PFD (from $10.03 \pm 0.3$ to $7.5 \pm 0.2 \mathrm{~g} \mathrm{diet} /$ day). However, the MLa group, when compared with the NLa group, displayed a significantly greater FIR which was $69.6 \%$ (from $12.8 \pm$ 0.25 to $3.9 \pm 0.5 \mathrm{~g}$ diet/day) during the first period and $65.2 \%$ (from $11.2 \pm 0.4$ to $3.9 \pm$ $0.2 \mathrm{~g}$ diet/day) during the second.

Figure 2 shows the experiments with the 60-day-old animals that were malnourished during the first 10 days of lactation (ML) or normally nourished (NL) during development and after the introduction of the PFD at

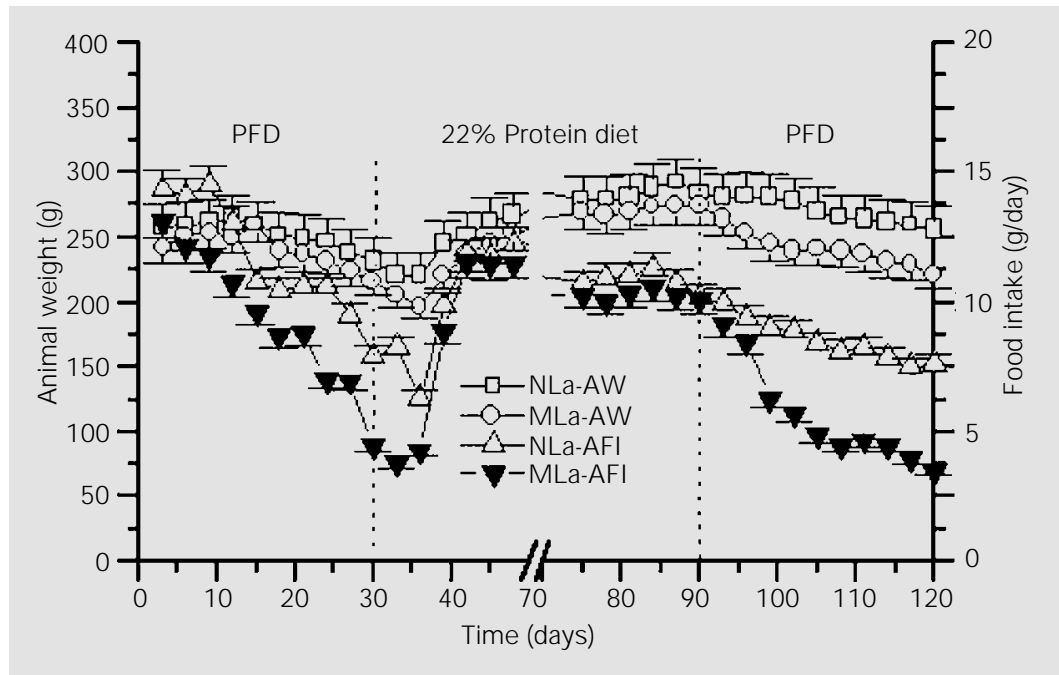

Figure 1. Animal weight (AW) and food intake (AFI) of one-year-old offspring from dams normally nourished (NLa-AW and NLa-AFI) or dams malnourished during the first 10 days of lactation on a protein-free diet (PFD) during two periods of 30 days (MLa-AW and MLa$\mathrm{AFI})$. Data are reported as means $\pm \mathrm{SEM}(\mathrm{N}=6)$. A significant difference was observed between NLa-AFI and MLa-AFI after changing the control diet to the PFD $(P<0.001$, ANOVA). 

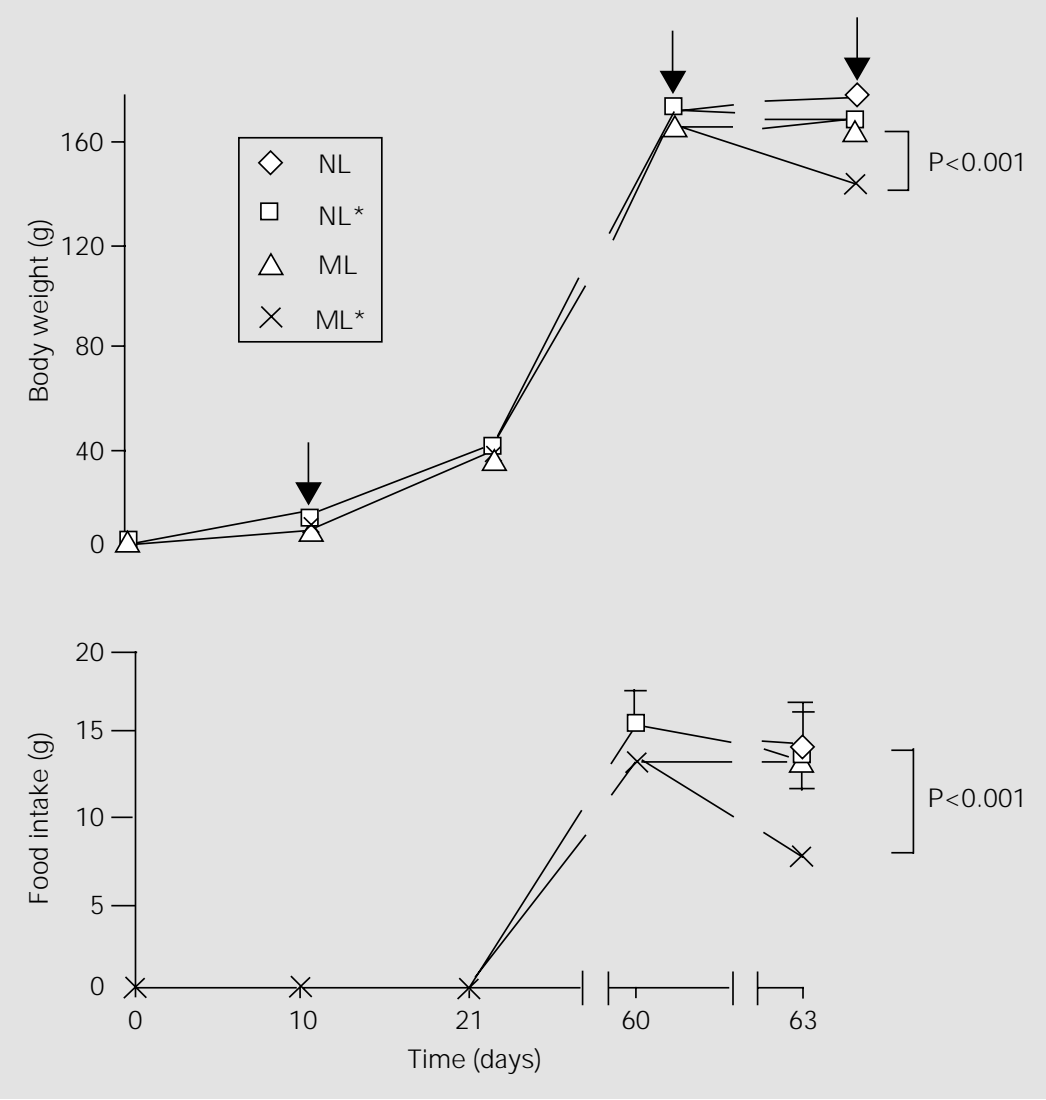

Figure 2. Animal body weight (upper panel) and food intake (lower panel) of rats from dams normally nourished $(\mathrm{NL})$ or malnourished $(\mathrm{ML}$ ) with a protein-free diet (PFD) during the first 10 days of lactation. At 60 days of age both groups were submitted to a PFD (groups NL* and $M L^{*}$ ). Significant differences in animal body weight and food intake were observed between NL* and ML* at 63 days ( 3 days of PFD). The arrows indicate the time (age) when independent groups were sacrificed to collect blood for insulin and leptin measurements. Data are reported as means \pm SEM $(N=6)$.

Figure 3. Plasma insulin (A) and leptin concentration (B) of rats from dams normally nourished (NL) or malnourished (ML) with a protein-free diet (PFD) during the first 10 days of lactation. NL10 and ML10 represent the hormone concentration of animals at 10 days of age. NL60 and ML60 represent the animals submitted to the above treatment at 60 days of age and NL63 and ML63 correspond to animals that were later fed a PFD during the last 3 days (from 60 to 63 days). $* P<0.01$ and $* * \mathrm{P}<0.001$ compared to control at same age and 3 days after PFD (Student t-test and ANOVA).
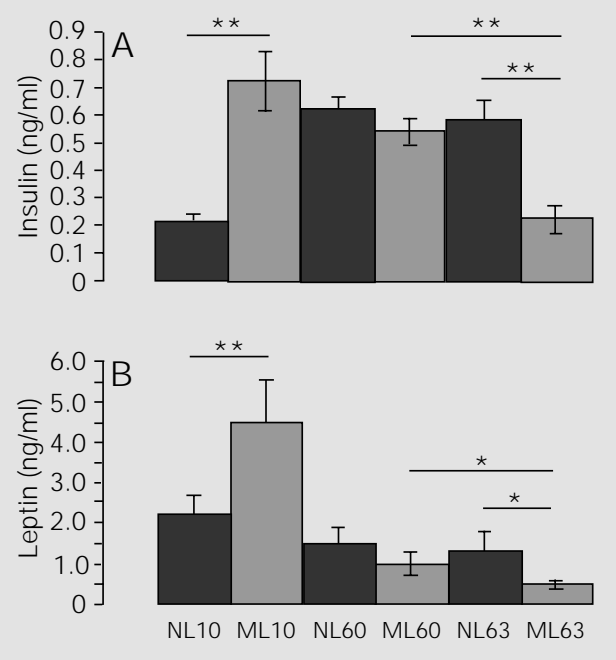

60 days. As described for the older animals, in these ones (60 days old) the association between body weight and food intake after a period of PFD (3 days) was significantly different. Basically, the animals from the NL group, whose diet was not changed at 60 days, maintained the weight gain until the end of the experiment (63 days). Both groups malnourished with the PFD at 60 days displayed a different weight reduction when compared with the weight at 63 days (NL: $175.3 \pm 5$ to $\mathrm{NL}^{*}: 168.5 \pm 9 \mathrm{~g}(9.6 \%) v s \mathrm{ML}:$ $166.6 \pm 6$ to $\mathrm{NL}^{*}: 144.9 \pm 4 \mathrm{~g}(8.2 \%)$, $\mathrm{P}<0.001)$. As shown in Figure 2, the FIR of the previously malnourished animals was higher than control. The impact of the PFD on the FIR was $41.4 \%$ (ML: $13.3 \pm 3$ to ML*: $7.8 \pm 1 \mathrm{~g}$ diet/day, $\mathrm{P}<0.001)$. In contrast, the reduction of FIR in the NL group submitted to the PFD from day 60 to 63 was only $14.2 \%$ (NL: $15.5 \pm 2$ to NL*: $13.3 \pm 0.5 \mathrm{~g}$ $\operatorname{diet} /$ day).

Figure 3 illustrates the plasma insulin and leptin concentrations of the NL and ML groups at different ages. At 10 days ML pups presented a significant increase of insulin when compared to NL (NL10: $0.22 \pm$ 0.03 vs ML10: $0.73 \pm 0.12 \mathrm{ng} / \mathrm{ml}, \mathrm{P}<0.001)$. Also, the leptin concentration of ML was significantly higher (NL10: $2.25 \pm 0.4 v s$ ML10: $4.6 \pm 0.8 \mathrm{ng} / \mathrm{ml}, \mathrm{P}<0.001)$. Nevertheless, at 60 days of age no difference was observed in insulin or leptin concentrations between NL and ML (insulin - NL60: $0.61 \pm$ 0.4 vs ML60: $0.54 \pm 0.3 \mathrm{ng} / \mathrm{ml}$; leptin NL60: $1.43 \pm 0.5$ vs ML60: $1.03 \pm 0.25 \mathrm{ng} /$ $\mathrm{ml})$. On the other hand, after both groups were submitted to the 3 days of PFD, the ML group displayed a significant reduction in insulin (NL63: $0.58 \pm 0.02$ vs ML63: $0.21 \pm 0.5 \mathrm{ng} / \mathrm{ml}, \mathrm{P}<0.001)$ and leptin concentration (NL63: $0.12 \pm 0.025 v s$ ML63: $0.5 \pm 0.05 \mathrm{ng} / \mathrm{ml}, \mathrm{P}<0.001)$. By contrast, there was no effect of PFD on the insulin or leptin concentration of the 63day-old rats nourished normally during lactation. 


\section{Discussion}

Our study showed for the first time that a PFD fed to the dams during early lactation induced in the offspring when adults (2 months and 1 year old) a different feeding pattern when compared with animals whose dams were fed a normal diet. This effect clearly reflects a metabolic imprinting effect on feeding behavior. Basically, the animals malnourished during early lactation, when submitted to a different diet reduced their food intake in a more marked way than normally nourished animals. We suggest that this appetite-dampening process was associated with the type of nutrition early in life and once acquired was sustained throughout the life of the animal.

In this study we hypothesized that leptin and insulin levels may be associated with the observed onset of the feeding pattern. For instance, in humans, leptin increases at the end of gestation, continues to increase at the beginning of lactation and then starts declining until adulthood (20-22). These data observed for humans are emphasized in our study with animals fed a control diet, in which we observed higher leptin levels in 10-day-old rats compared with 60-day-old rats. Moreover, this hormone profile was found to be more prominent in animals malnourished during early lactation, with our data showing that PFD induced a high plasma concentration of leptin and insulin when the undernourished animals were compared with controls at 10 days.

The 60-day-old animals undernourished during early life displayed a reduced food intake when the diet was replaced with the PFD. In comparison with the 10-day-old animals, leptin and insulin concentrations were found to be reduced and at 63 days of age, after 3 days of PFD, were found to be even more reduced when compared with those at 60 days. These data allow us to hypothesize that the high levels of these hormones in the malnourished animals at 10 days of age may also increase the hypothalamic sensitivity to leptin. In other words, at 60 days the regulatory control mechanisms of feeding behavior in early-life malnourished animals were quite satisfactory for food restriction. This observation supports the idea that restricted feeding early in life should determine long-term resetting of major hormonal axes, such as insulin and leptin, thus controlling energy homeostasis and body weight.

It has been suggested that insulin and leptin are involved in the modulation of neuropeptide $\mathrm{Y}$ for setting the long-term body weight. For instance, it has been described that diets rich in carbohydrates rapidly increase the expression, synthesis and release of hypothalamic neuropeptide Y (23). Also, recent observations have shown that food availability and intake induce a profound effect on the neuropeptide $\mathrm{Y}$ receptor in normally nourished or malnourished rats $(8,24,25)$. Therefore, we may suggest that by increasing leptin and insulin, the feeding behavior and energetic utilization were balanced. Also, the high level of these two hormones may reflect an adaptive process oriented towards animal survival in an environment deprived of nutrients. For instance, the fact that leptin increases glucose uptake and GLUT4 recruitment (26) reinforces the idea that at 10 days of age the malnourished rats adapted their feeding behavior to a lower food (milk) availability to optimize the nutrient (glucose) utilization (high insulin).

Despite the fact that the aim of the present study was not to identify the underlying mechanisms of the recently discussed process of "metabolic imprinting or programming" $(27,28)$, our data suggest that during the postnatal period leptin and insulin may be associated with energy intake and expenditure, growth and feeding reprogramming due to malnutrition. 


\section{References}

1. Ravelli GP, Stein ZA \& Susser MW (1976). Obesity in young men after famine exposure in utero and early infance. New England J ournal of Medicine, 295: 349-353.

2. Barker DJ (1995). Fetal origins of coronary heart disease. British Medical J ournal, 311: 171-174.

3. McKeigue PM (1997). A life-course approach to chronic disease epidemiology. In: Kuh D \& Bem-Shlomo Y (Editors), Life Course Influences on Adult Disease. Oxford University Press, Oxford, UK, 78-100.

4. Widdowson EM \& McCance RA (1963). The effect of finite periods of undernutrition at different ages on the composition and subsequent development of the rat. Proceedings of the Royal Society of London. B, Biological Sciences, 158: 329-342.

5. Halaas J L, Gajiwala KS, Maffei M, Cohen SL, Chait BT, Rabinowitz D, Lallone RL, Burkey SK \& Friedman J N (1995). Weightreducing effects of the plasma protein encoded by the obese gene. Science, 269: 475-476.

6. Campfield LA, Smith FJ , Guisez Y, Devos R \& Burn P (1995). Recombinant mouse ob protein: evidence for a peripheral signal linking adiposity and central neural networks. Science, 265: 546-549.

7. Schwartz MW, Woods SC, Porte D, Seeley R \& Baskin DG (2000). Central nervous system control of food intake. Nature, 404: 660-671.

8. Plageman A, Wass T, Harder T, Rittel F, Ziska T \& Rhode W (2000). Hypothalamic neuropeptide $Y$ levels in weaning offspring of low-protein malnourished mother rats. Neuropeptides, 34: 1-6.

9. Saladim R, De Vos P, Guerro-Millo M, Girard J \& Staels B (1995). Transient increase in obese gene expression after food intake or insulin administration. $\mathrm{Na}$ ture, 377: 527-529.

10. Kolaczynski J W, Nyce MR, Cosidine RV, Bodem G, Nolam J J , Henry R, Mudalaim SR, Olesky J \& Can J F (1996). Acute and chronic effects of insulin and leptin production in humans: studies in vivo and in vitro. Diabetes, 45: 699-706.

11. Ozane SE \& Hales CN (1999). The longterm consequences of intra-uterine protein malnutrition for glucose metabolism.
Proceedings of the Nutrition Society, 58: 615-619.

12. Holness MJ, Langdown $M L \&$ Sugden MC (2000). Early life programming of susceptibility to regulation of glucose metabolism and the development of type 2 diabetes mellitus. Biochemical J ournal, 349: 657-665.

13. Barbosa FB, Gravena C, Mathias PCF \& Moura AS (1993). Blockade of phosphate flush of pancreatic cells from adult rats undernourished during early lactation. Brazilian J ournal of Medical and Biological Research, 26: 155-158.

14. Moura AS, Carpinelli AR, Barbosa FB, Gravena C \& Mathias PCF (1996). Malnourishment during early lactation as an alternate model to study the onset of diabetes mellitus. Research Communications in Molecular Pathology and Pharmacology, 92: 73-83.

15. Moura AS, Filho J SC, Mathias PCF \& Franco de Sa CCN (1997). Insulin secretion impairment and insulin sensitivity improvement in adult rats undemourished during early lactation. Research Communications in Molecular Pathology and Pharmacology, 96: 179-192.

16. Grigor MR, Poczwa Z \& Artur PG (1986). Milk lipid synthesis and secretion during milk stasis in the rat. J ournal of Nutrition, 116: 1789-1797.

17. Mathias PC, Salvato EM, Cury $R \&$ Malaisse WJ (1993). Effects of epinephrine on ${ }^{86} \mathrm{Rb}$ efflux, ${ }^{45} \mathrm{Ca}$ outflow and insulin release from pancreatic islets perifused in the presence of propanolol. Hormone and Metabolic Research, 25: 138141.

18. Desbuquois B \& Aurbach GD (1971). Use of polyethylene glycol to separate free and antibody-bound peptide hormone in radioimmunoassays. J ournal of Clinical Endocrinology and Metabolism, 33: 732738.

19. Reeves PG, Nielsen FH \& Fahey GC (1993). Ain-93 purified diets for laboratory rodents: final report of the American Institute of Nutrition ad hoc Writing Committee on the Reformulation of the Ain-76a Rodent Diet. J ournal of Nutrition, 123: 1939-1951.
20. Geary $M$, Herschkovitz R, Pringle PJ Rodeck CH \& Hindmarch PC (1999). Ontogeny of serum leptin concentrations in humans. Clinical Endocrinology, 51: 189192.

21. Baskin DG, Figlewicz LD, Seeley RJ, Woods SC, Porte D \& Scwartz MW (1999). Insulin and leptin: dual adiposity signals to the brain for the regulation of food intake and body weight. Brain Research, 848: 114-123.

22. Shubring $C$, Siebler T, Kratzsch J , Englaro P, Blum WF, Triep K \& Kiess W (1999). Leptin serum concentrations in healthy neonates within the first week of life: relation to insulin and growth hormone levels, skinfold thickness, body mass index and weight. Clinical Endocrinology, 51: 199-204.

23. Wang J , Dourmashkin J T, Yun R \& Leibowitz SF (1999). Rapid changes in hypothalamic neuropeptide $Y$ produced by carbohydrate-rich meals that enhance corticosterone and glucose levels. Brain Research, 848: 124-136.

24. Kosak R, Burlet $A$, Burlet $C \&$ Beck $B$ (2000). Dietary composition during fetal and neonatal life affects neuropeptide $Y$ functioning in adult offspring. Brain Research Development, 125: 75-82.

25. Kosak R, Mercer J C, Burlet A, Moar KM, Burlet C \& Beck B (1998). Hypothalamic neuropeptide $Y$ content and mRNA expression in weanling rats subjected to dietary manipulations during fetal and neonatal life. Regulatory Peptides, 75-76: $397-$ 402.

26. Bertil L \& Gammeltof S (1999). Leptin stimulates glucose uptake in $\mathrm{C} 2 \mathrm{C} 12$ muscle cells by activation of ERK2. Molecular and Cellular Endocrinology, 157: 121-130.

27. Lucas A (1994). Role of nutritional programming in determining adult morbidity. Archives of Disease in Childhood, 71: 288290.

28. Waterland RA \& Garza C (1999). Potential mechanisms of metabolic imprinting that lead to chronic disease. American J oumal of Clinical Nutrition, 69: 179-197. 